\title{
The Theory of the Selfish Gene Applied to the Human Population
}

\author{
Richard Startup \\ Honorary Research Fellow, Swansea University, Swansea, Wales, UK \\ Email: r.startup@swansea.ac.uk
}

How to cite this paper: Startup, R. (2021). The Theory of the Selfish Gene Applied to the Human Population. Advances in Anthropology, 11, 179-200.

https://doi.org/10.4236/aa.2021.113012

Received: January 26, 2021

Accepted: August 6, 2021

Published: August 9, 2021

Copyright (c) 2021 by author(s) and Scientific Research Publishing Inc. This work is licensed under the Creative Commons Attribution International License (CC BY 4.0).

http://creativecommons.org/licenses/by/4.0/

\begin{abstract}
In a study drawing from both evolutionary biology and the social sciences, evidence and argument is assembled in support of the comprehensive application of selfish gene theory to the human population. With a focus on genes giving rise to characteristically-human cooperation ("cooperative genes") involving language and theory of mind, one may situate a whole range of patterned behaviour-including celibacy and even slavery-otherwise seeming to present insuperable difficulties. Crucially, the behaviour which tends to propagate the cooperative genes may be "at cost" to the genes of some who may be party to the cooperation itself. Explanatory insights are provided by Trivers' parent-offspring conflict theory, Lack's principle, and Hamilton's kin selection mechanism. A primary observation is that cooperation using language and theory of mind is itself interdependent with full human conceptualization of a world of objects and of themselves as embodied beings. Human capacities inhering in, or arising out of, the ability to cooperate are also responsible for a vitally important long-term process, the domestication of animals and $\mathrm{p}$ lants. The approach illuminates the difference between animal and human sexual behaviour, and the emergence of kinship systems. Again, recent patterns of population growth become much more explicable. It is argued that the gene is the single controlling replicator; the notion of the meme as a second independent replicator is flawed.
\end{abstract}

\section{Keywords}

Selfish Gene, Human Co-Operation, Theory of Mind, Division of Labour, Meme

\section{Introduction}

Darwin was unfamiliar with the notion of a gene. However, in the first half of 
the twentieth century, the Darwinian theory of evolution and the new understanding of genetics were synthesized. Then building upon various other theoretical contributions (e.g. Williams, 1966a) the notion of the selfish gene was introduced (Dawkins, 1976, 2006) and has since become highly influential (Grafen \& Ridley, 2006). That theoretical development has proved to have considerable explanatory power by expressing a gene-centred view of evolution as opposed to the original organism-focused Darwinian approach. The notion assists understanding of such behaviour as one organism behaving in a seemingly selfless way in relation to another closely genetically-related one, the most familiar example being mammalian maternal behaviour in relation to her off-spring. The core idea is that genes which tend to get passed on are ones which have consequences which in turn "serve the interests of the genes" in the sense of increasing the likelihood of their survival and further propagation. Thus the behaviour of a mother may sometimes be at risk to herself while nevertheless tending to increase the likelihood of those of her genes shared with her off-spring (one half) surviving.

It is essential to be clear what is meant by "selfish" in this context. Emphatically, it does not mean that individuals with the genes would tend to act in selfish ways. Rather the idea is that the genes, in a certain sense, act only for themselves; their only "interest" is in their own replication-to be passed on to the next generation. Should it be the case that, because of their action, some other genes, e.g. those carried by other organisms, lose out by failing to replicate, that is simply an unfortunate-for-them consequence. Of course, it is the case that genes do not "want" or "intend" anything, but it has turned out to be convenient and suggestive shorthand to focus on their selfishness in this specific sense. At root, what is being got at is the notion that genes that act in a particular way, e.g. give rise to particular types of behaviour, are more likely to get passed on, even though this may be "at cost" to other genes. They have, as it were, power as replicators.

This is an attempt to test the theory of the selfish gene in relation to the human population. It takes something of the form of a feasibility study, whereby the aim is to judge whether patterns in human life may be interpreted within that theoretical context. In this connection, it is important to acknowledge that many evolutionary biologists working on human behaviour adhere to the indicated general perspective, but there is a discernible tendency among them to equivocate on the central issue, partly to avoid having to confront counter-arguments from social scientists. There are felt to be problems with such phenomena as priestly celibacy or use of contraceptives which are hardly behaviours which promulgate the genes of those involved.

There is also the familiar orienting notion that in humans' cultural evolution in some sense "takes over" from biological evolution. Quite reasonably too, it may initially be felt to be unpromising theoretically to attempt to subsume under a single explanatory concept, on the one hand, patterns of animal behaviour which are sometimes properly to be characterized as stereotyped, and on the other, patterns of human behaviour which may be conceptualized as frequently ra- 
tional and flexible. Certainly, any move in this direction would need to acknowledge cultural variations but without "culture" forming a primary explanatory concept.

In fact, this line of thought involves conceptual confusion. It is one thing to say that there is a single evolutionary framework, but there is a big difference between saying that genes determine behaviour directly and saying that they determine behaviour indirectly through complex decision-making processes. The former works at the level of simple organisms, the latter is how it works in complex organisms such as mammals, and especially primates (Santos \& Rosati, 2015). What might be true of insects is not true for higher vertebrates who make complex decisions on a moment-by-moment basis. Basically, the point of having a big brain is to be able to adjust behaviour strategically and tactically in response to local circumstances. What is determined genetically here is not the behaviour but the capacity to make a decision that optimises output by solving local problems (a process known as "satisficing") and thus contributing indirectly to genetic fitness (Reuter \& Montag, 2016).

It is envisaged that in the passage from the purely hominid to Homo sapiens, genetic change took place so that humans could (and subsequently did) cooperate using language and theory of mind (in contrast to the cooperation manifested by purely animal species). In this connection, oral language use may in itself take the form of a type of cooperation or it may also stimulate or be interdependent with other types of cooperation (Dunbar, 1996). In respect of the ways language may be deployed, five possible types of speech acts may be distinguished (Searle, 2010: p. 69). What is being got at by reference to "theory of mind" is the human ability to attribute mental states to others, to theorise how other humans' thought processes work e.g. to grasp their intentions and reasons for action (Carruthers \& Smith, 1996); that ability is itself enhanced by language use.

Since prior to this genetic change there would already have been patterned interaction between close blood relatives, it is important to make clear that, following the change, cooperation of the type indicated is possible between both those with and those without blood ties. While there have been attempts to understand cooperative behaviour in evolutionary terms, for instance by considering strategies giving rise to it (e.g. Axelrod, 1984), those approaching human behaviour utilizing the notion of the selfish gene have not focused their account - as is being done here-on the notion of genetic change giving rise to characteristically-human cooperative behaviour. It is fully recognized that genetic change which is here encapsulated in a phrase will have occurred in stages over a long period of time. There may be expected to be differences in relevant respects from and among such beings as Australopithecus, Homo habilis, and Homo ergaster (see Dawkins, 2010: pp. 196-197) which are germane to their length of survival and eventual extinction.

So an attempt is here made to test the effective explanatory power of the application of the notion of the selfish gene to the human population focusing on 
human genes giving rise to cooperation, or "cooperative genes" as they may be called. The next important step is to identify the deep conceptual basis of human cooperation. It may be judged that this is interdependent both with the human use of language and their utilisation of theory of mind.

\section{The Conceptual Basis of Human Cooperation}

Plainly language develops only gradually-it changes continuously-and to understand its role it is necessary to take account of origins and antecedents. $\mathrm{Hu}$ mans evolved from other primates and one can speculate about aspects of the origins of language, but do so responsibly (Startup, 2019: pp. 456-457). Although we now know about an immense universe, the origins of language would lie in the perspectives of groups of preliterate peoples with close blood ties. Very roughly there must have been a passage from an animal world of sensation (where sensations are "private") through to a human grasp through language that existence is within "a world of objects" (where objects are "public"). Importantly, the latter understanding is not culturally variable but is common to all human groups (however much their vocabularies may vary), making it clear that it has a genetic source.

The world of objects-the physical world-roughly speaking consists of the two overlapping classes of things we can use-potential resources-but also obstacles or things we "come up against". Human bodies are numbered among the physical objects. Indeed they are to be construed as an essential feature, a foundational element of the physical world. This is to do with the fact that they necessarily have the same object status as things with which they are in contact or "touch". From the outset bodily differentiation is the primary way we are individuated as people.

It may be judged that the passage through to this type of understanding is indeed interdependent with both the nature of language and the use of theory of mind. On the first point one must note that language is public and primarily concerned with what is understood to be a public world: it could not work simply in relation to private sensations to which people in general have no access. Language is interdependent with the understanding that we exist within a world of objects because: 1) objects provide language with its primary content-they ensure language is "about" something; but 2) language enables people to "compare notes" on what may be experienced, for example seen or touched, given successive occupancy of what is understood through language to be the same place or differing places, hence they are able to identify a particular object; again, language enables what differing people may see or touch at differing times to be integrated into a broader understanding of "the situation" embracing several objects. For instance, it is through language that it becomes "common knowledge" or an established fact that a hill or river may be seen from a particular home base but is some distance from it. The persistence of objects is conceptually integrated with an emergent conception of the past and future.

On the second point one needs to reflect on what is involved in the use of 
theory of mind. To take a simple example: suppose a child is seen by a first observer to hide a thimble behind a screen so that it may not be seen directly by that observer. Then a second observer enters the room but takes up a different position within it. It could then be the case that the first observer immediately judges that the second observer from his or her position can directly see the thimble even though he himself or she herself cannot. This example illustrates the more general point that all the time in life we are shaping our behaviour in the light of our understanding of the perspective and purposes of others. Importantly, however, one has to have a conception of a physical object in a particular position to judge that another may see it (as with the thimble); again, one must understand another person to be in a particular position to judge what may be seen from that position. On the other hand, the implication goes rather in the opposite direction when one says that continual successful utilisation of theory of mind, as in this example, tends to be confirmatory of the understanding that we exist within a world of physical objects. Indeed the use of that theory helps to secure that understanding through extended time.

Given a focus on cooperation, the last four paragraphs could hardly be more important since the public world of objects (which includes humans themselves) is the stage upon/within which the elaborating drama of human cooperation is played out. Once objects are identified which are understood to persist in time humans can begin to develop and expand upon all the types of understanding with which we present-day humans are familiar (including those of a rudimentary technological or scientific type) which bear upon their interests and concerns e.g. they are enabled to gain more predictable access to their sources of food and water.

\section{The Material Basis for Human Cooperation; Group Augmentation Theory}

Importantly, population and population growth are material in their nature. From this point the world of objects-the material world-is potentially fully available to serve the interests of the cooperative genes, while human knowledge-initially very limited and distributed-is free to grow in an open-ended, unlimited, and increasingly integrated way. It is the combination of the two that holds out such promise for the cooperative genes.

In respect of the application of the theory of the selfish gene to humans, as already implied, the suggestion may arise that humans may be expected to be selfish; at least this may be a kind of default expectation. Let it be said without qualification: this is mistaken. It is mistaken for a particularly straightforward reason: humans need to cooperate to gain access to the means of their own subsistence. Hence applicable here is the group augmentation hypothesis (or mutualism) which is to the effect that if helpers in such cooperative groups raise the reproductive success of the group, then the benefits of living in a resulting larger group-improved survival or future reproductive success-favour the evolution of seemingly altruistic helping behaviour. Group augmentation selection applies 
to cooperative hunting and cooperative defence. It involves the group being able to do things more effectively than the individual can, but this serves the interests of the genes of individuals (Kokko, Johnstone, \& Clutton-Brock, 2001; Kingma et al., 2014). The implication is that some larger groups may be expected to emerge sustained by more effective cooperative behaviour.

It seems this was indeed the prominent behavioural pattern marking the emergence of modern humans in Africa. With respect to members of such human groups it is relevant to say that it is in their interests to cooperate for sustained periods, even if they also spend a lot of time bickering and quarrelling, as we know they do. Indeed conflict internal to a group (perhaps generational in its nature) may give rise to division or segmentation. Hence an important basic piece of evidence that the theory may apply concerns the fact that at the stage when it consisted of hunters and gatherers, the human population increased in numbers as it spread relatively thinly throughout the habitable continents. As part of this, the first colonization of the Americas from Alaska to Patagonia in perhaps as little as 2000 years is a particularly striking phenomenon (Diamond, 1998: pp. 37-47). The dispersal of the human population involved adapting to highly varied environments, made possible by cooperative behaviour in respect of such activities as hunting, provision of clothing and use of fire. As Darwin affirms species succeed that diversify their range.

Even today, when one feels the human population "eggs" are all carried within a much more integrated "island Earth", at least one can say that the pattern of dispersal on the planet offers some support to overall numbers from the destruction of individual habitats. The need for cooperation among humans is evident from the simplest societies to the most complex. Once humans use language to define the values and interests enabling them to live and flourish, realising and expressing those values and interests will require a high level of cooperation. Of course, at times there will be free riders but we cannot all be free riders all the time; it would also be in our interests to act against free riders e.g. by punishing or shaming them (Bowles \& Gintis, 2013: pp. 186-191).

\section{The Normative Element in Cooperation; the Division of Labour}

The last observation dramatises the point that a normative (or "deontological") element tends to come to inhere in sustained cooperation of any type. When an instance of cooperation is in train, whether or not individual parties will follow through is typically in doubt or at issue; we "rely" on others. Now the pattern of cooperation would not have evolved if there were not an overall tendency for cooperation to be successful; it is cooperation carried through which delivers the benefits. The key development in humans making this possible involves the process of "internalisation": basically the person has come to feel they ought, at least to some degree, to be "reliable".

In a modern society a whole vocabulary concerned with issues of trust focuses on this key area. Thus it may be judged that in the generality of the human situa- 
tion the need for cooperation is the crucible for the emergence of morality, which is of course bound up with how the scope of normative expectations becomes extended to wider populations. As it does so, morality constitutes a source of stabilizing regulation: the achievement of goals on a cooperative basis becomes more predictable. At the risk of over-dramatising, the greatest single achievement is the prevention of a Hobbesian "war of all against all”. From the outset this tends to be avoided by emergent morality together with the patterning of interests and values; plainly too, the long-term build up of institutions of social control makes a decisive contribution. The patterning and regulation of behaviour provides context for population growth.

The existence of a normative element within cooperation has further significant implications. It means that humans can have reasons for action which are "desire-independent"; they can choose to "delay gratification". By contrast, prehuman behaviour would be "desire-dependent". What is being got at here is that humans can work towards something which is not intrinsically desired, but is understood to be a step towards or means towards something else which is desired. Closely related is the phenomenon of inhibition, the pattern whereby an individual wants or desires something but refrains from its direct and immediate pursuance because of internalized constraint. Cooperation thus involves virtually from the outset means-ends orientation and a delayed gratification pattern. Humans can foresee what is needed to achieve a desired objective, can plan, and attempt to work through the various required stages, some or many of which are not desired intrinsically.

In this connection a particularly useful capacity which humans possess and which distinguishes them from other animals is their ability comprehensively to copy i.e. to copy in any respect or any aspect. This is of the greatest value in practice since it enables them to duplicate what are judged to be effective ways of doing things. Moreover this ability may steadily expand in scope given a context of human cooperation taken together with full conceptualization of the material world. For instance, copying (duplicating) a structure such as a tool or a shelter is feasible given full conceptualization of the world of objects, but it may reasonably be doubted whether this would be possible in (say) a world of sensations. The phenomenon of copying seems to be associated with the ability to adopt a third-person perspective which itself arises out of cooperation.

Building upon the ability to copy, characteristically-human cooperation directly opens the way to an almost indefinitely extended and highly flexible elaboration in the human division of labour, to be contrasted with the rudimentary and in a sense "stereotyped" one observable in higher animals. Utilising theory of mind one individual may not just understand the role of another person (e.g. in the way the pupil grasps the role of the teacher) but may begin to see how to perform that role themselves; they are, in sum, able to "take the role of the other" (Blumer, 1969). The fact that almost anyone can minimally act on the stage points in the same direction. Now, of course it is the case that many roles require training and the acquisition of skill to enable one to perform them at all well, but 
these more specialized aspects could themselves be imparted through a set of cooperative relationships in situations where there are already practitioners around (as with craftsman and apprentice). The elaboration of the division of labour evident in any society and its massive elaboration in one like ours arise out of the phenomenon of characteristically-human cooperation: no other essentially different additional capacity in humans needs to be postulated. Yet the phenomenon of the elaboration and specialization of labour is at the root of both simple and complex human societies; indeed it may be identified as the key source of population growth. However, the significance of this particular observation becomes clearer once one reflects on the implications of the point that the cooperative genes may be considered as "selfish".

\section{The Importance of Aggregates Rather Than Individuals}

It follows from the theory of the selfish gene that, in becoming established, new genes such as these give rise to behaviour which tends in the next and then subsequent generations to promulgate the new genes themselves (the influence of genes may hence be thought of as "reflexive") i.e. in this case the genetic change would tend to give rise to a large and increasing population of people with the new cooperative genes. As already indicated, it also follows from the theory that this tendency for new genes to give rise to behaviour tending to promulgate themselves may be "at cost" to the promulgation of other genes: as has been stressed, this is what is meant by calling the genes "selfish".

It is envisaged that the above applies here i.e. that the promulgation of the new genes can be expected to be "at cost" to the promulgation of other genes. In particular, since cooperation always involves more than one person an absolute expansion in the population of people able to cooperate may be accompanied by a relative or absolute failure to promulgate the genes of individuals or classes of people some of whom may be party to the cooperation themselves. Fundamentally, in respect of the new "cooperative genes", it is the overall growth in numbers of cooperating people which matters, while there may be identifiable "winners" and "losers" as a consequence of that cooperation itself. There may, for instance, be identifiable persons or categories with high or low fertility, or high or low mortality.

Example (1): At various times in Eastern societies there has been the institution of the ruler's harem with attendant eunuchs. Genetic studies estimate that $0.5 \%$ of all males in the world alive today are the descendants of Genghis Khan and his siblings (and 7\% within the boundary of the Mongol empire; Zergal et al., 2003). These types of arrangements have massive genetic and evolutionary consequences for some individual lineages at the expense of others.

Example (2): In northwest Germany in the eighteenth century most of the population consisted of small-holders and landless labourers. Small-holders represented just $20 \%$ of the population in 1720 , but 150 years later their descendants represented $80 \%$ of the population because the mortality of landless labourers was so great (Voland, 1990). 
Example (3): The Roman Catholic Church has been a central institution in many societies and incorporates cooperative behaviour between those at the same or differing levels within a hierarchy. That church has encouraged growth in the human population e.g. by proscribing the use of manufactured contraceptives and suicide. The tendency to promote growth in numbers is nevertheless "at cost" to the genes of the celibate priesthood.

Example (4): Ancient societies such as Greece and Rome were based on slavery yet their populations rose for extended periods. Within a slave-owning society the age-specific mortality rates and the overall mortality rate of the slaves may be expected to be higher than those of the slave-owners, yet there can be a tendency nevertheless for population numbers to rise. The overall growth in numbers is "at cost" to the genes of some of the slaves.

The institution of slavery is, perhaps surprisingly, instructive for present purposes. In an unexpected way that institution, ubiquitous in antiquity, points up the significance of a very important type of cooperation for present purposes-that which is coerced. Slaves tended to originate from those defeated in battle. They could have been killed but there is gain in product from putting them to work. The males could be castrated or maimed, but, again, there can be a net gain from instead allowing them to breed, thereby providing a continuous supply of slaves. In connection with slavery coerced cooperation is advanced while the mortality which could have followed defeat is reduced. Notably too, slavery is found in otherwise widely differing cultures and contexts. There is the added point that female slaves were often taken over as concubines in all these societies. For instance the Icelandic Viking family sagas frequently refer to female "Irish" (meaning Celtic) slaves, and indeed $80 \%$ of living Icelandic women have Celtic mtDNA (inherited only down the female line) (Helgason et al., 2000).

To put the position generally, one can say that cooperation (which will be occurring simultaneously at differing levels within a complex society) tends to give rise to a growing population but also to differentials in the vital rates of fertility, mortality and migration between sub-populations which are governed by the nature of the cooperation itself. In this connection one must be sensitive to the existence of differing kinds of aggregates. Familiar from ecology is the important distinction between aggregations (herds) and congregations (stable social groups) (These are very different and make very different cognitive demands on their members. Primates have the latter, which is why they have such big brains). Among humans one finds both social groups and social categories producing differentials. Regarding the latter, it is evident that within advanced societies and arising out of the division and specialisation of labour, there are differentials in fertility and mortality within and between social class categories, one source being the differentially hazardous nature of individual occupations.

The demographic patterns at the present time across vast swathes of the Earth's surface point firmly to the emphasis here on the importance of aggregates as against individuals. At the present time the world population is growing steadily and sustainably, at any rate in the short- to medium-term, but the pro- 
portion of that population who are paying a substantial cost in terms of the loss of their own potential fertility is also growing; this is strikingly the case in Europe and Japan, where some national populations are even in decline. The European pattern of small family size is becoming much more widespread. Individuals are evidently not generally acting in ways which maximize the likelihood of the promulgation of their own genes. Hence an attempt to account for behaviour by reference to the selfish gene on an individualized basis would plainly fail. However, once the move is made to foreground cooperative genes observable patterns become explicable. Paradoxically, the overall world population is growing while many, perhaps most, individuals are "paying a substantial cost" in terms of the loss of their own potential fertility.

\section{A Best-of-a-Bad-Job Strategy}

In ordinary parlance the word "cooperation" tends most often to be used when the parties are acting (wholly) willingly; but, as implied above, its usage must not be so confined here. The patterns in human life would not remotely be as they are in the absence of coerced cooperation and, importantly, there are degrees of coercion. Slavery is to be understood as a type of cooperation, albeit subject to massive constraint; the slave may perhaps in his or her work be described as cooperating "minimally". Further comment is appropriate, however, since many evolutionary biologists might be disinclined to see it as cooperation as such; there is a need to situate it in evolutionary terms. Focusing on the slave, roughly speaking it is a classic best-of-a-bad-job strategy from an evolutionary point of view; where those less favoured use alternative reproductive tactics to minimize their disadvantage (Dawkins, 1980). In this case slavery is better than death, because at least a slave has some chance of surviving to reproduce and the next generation may do much better. This was, in fact, the issue faced by war-chiefs among the nineteenth century Cheyenne. The peace-chief role was hereditary and they never fought with war-bands; but war-chiefs did and they took an oath never to leave the field of battle alive unless victorious (Dunbar, 1991; Keeley, 1996). The payoff was that if they survived, they could demit from their oath and return to conventional society, where they were a great attraction to the opposite sex, so they did very well indeed reproductively (even compared to peace-chiefs). Their initial problem it transpires was that they were originally all orphans, slaves and others from the dregs of society who had no hope of marriage because of their status. Hence it was a high risk/high gain strategy, and many did not succeed. They had very limited options, as is usual for the losers in tribal war. Hence one is able to situate slavery from an evolutionary point of view.

\section{Domestication}

A further long-term process of the utmost importance for population growth is the domestication of animals and plants (Petersen, 1969: p. 348). Given the theory being evaluated, it is highly significant that it is human capacities inhering in, or arising out of, the ability to cooperate which give rise to domestication. 
Essentially, humans relate to animals using theory of mind and the capacity to "take the role of the other" even though the animals themselves do not (fully) reciprocate. To take a striking example, a shepherd signals to his or her dog given the shepherd's understanding of the view the dog has of a flock of sheep i.e. in an imaginative sense the shepherd "takes the role" of the dog. In general, human action leading to animal or plant domestication is informed by implicit or explicit understanding of an animal's or plant's life process e.g. 1) from a position near a campfire a man throws a piece of meat to a wolf; 2) a woman wishes a plant to grow so she removes weeds and waters it. There is a sense in which the human agent is "looking at life" from the wolf"s or plant's point of view; he/she is serving the "interests" of the genes of that particular animal or plant.

There again, through time multifarious qualities of differing types are selected for in the human population - the gene pool changes in patterned ways for extended periods; one may even be tempted to speak of human "domestication" (Pagel, 2012: Chapter 3)-but a key point is that judgments as to the "fitness" of particular categories can only be made relative to an environment increasingly shaped by cooperation. Thus impractical people may now be accommodated in "ivory towers"! The qualities selected for in animals and plants tend to serve cooperatively-defined human interests, while those selected for in the human population tend to make the overall pattern of cooperation easier to sustain or expand.

\section{Key Elements of the Social Fabric}

Given our animal nature, plainly sexual bonds and relations between blood relatives represent a vital basis but both are changed with the coming of characteristically-human cooperation. Regarding sex the key point is that there arises a range of options, which means that the potential for sex to be an ingredient of differing types of cooperative relationship (no doubt characterized by differing patterns in power relations) and, in particular, its ability to be economically significant, increases. Importantly, the sexual tie may underpin the couple (or family) as a unit of economic production or consumption.

Absolutely vital is the way in which cooperation, on the basis of on-going ties between blood relatives, gives rise to the different but related phenomenon of kinship i.e. the social recognition of blood ties; but it is abundantly apparent that, at the same time, this is the source of a variety of kinship systems i.e. it generates cultural variation (Fox, 1984: p. 39; Startup, 2014: pp. 83-84). There is the broad contrast in pre-literate societies between matrilineal and patrilineal systems, the latter reckoned by Fox (1984: p. 114) to be the "neater" institutional solution to potential conflict problems. In this context marriage comes to define the position of off-spring, bearing, for instance, on issues of inheritance and succession. A framework of affinal and kinship links both renews and integrates society (Beattie, 1993). This is the primary system of co-action and coordination facilitating population growth. 


\section{The Importance of Trivers' Parent-Offspring Conflict Theory and Lack's Principle}

The pattern of that growth, however, may only be understood with the help of additional biological principles. Consider, for instance, the aforementioned case of the celibacy of the Roman Catholic priesthood. The celibacy pattern may at first sight look like genetic "altruism", but on closer inspection it lends itself to a different interpretation. Roughly speaking, it almost invariably turns out to owe something to "parental manipulation" of offspring, a pattern pointed up in Trivers' parent-offspring conflict theory (Trivers, 1974; Haig, 1993). In this connection, there are many clear well-studied examples, from the Tibetans to the late medieval Portuguese nobility to the aforementioned peasant farmers of 18th and 19th century north-west Germany. The problem is always shortage of land and how to manage (genetic) lineage survival into future generations under ecological constraint, where constant division of family land generation after generation would quickly result in impoverishment and extinction.

In the German case (Voland \& Beise, 2002) to prevent economic disaster (i.e. being reduced to landless labourers), the smallholders operated what the historians call an heir-and-spare strategy on their sons (but not daughters!) - one to inherit the family farm and a backup in case he died. The mortality rate on subsequent sons was $50 \%$ in the first 12 months of life, which parents were aware of and which shaped their behaviour (e.g. as reflected in their allocation of god-parents). Turning to consider Irish evidence, analysis of seminary entries in Antrim during the late nineteenth century shows that seminarians came mainly from large families with a lot of boys, and were invariably the younger ones.

The underlying reason for this pattern is that humans, in particular, maximise fitness by maximising lineage survival, which is all about optimising parental investment in offspring, not by maximising parental investment in each offspring. This is a general principle in evolutionary biology known as Lack's Principle that was worked out in the 1950s in studies of robins and other small UK birds. Lack found that birds adjust the clutch size to correspond to the largest number of young for which the parents can, on average, provide enough food, with a spare to allow for some natural losses along the way (Lack, 1954; Williams, 1966b).

\section{The Social Contract}

The last sections concern family and lineage phenomena, but a key concern is with the emergence of larger human groups. In this connection, a suggestive orienting idea (as it has proved to be in other social and philosophical contexts) is that of the "social contract". Fundamentally, primate societies are in effect implicit social contracts: they live in stable social groups (primarily to avoid predation, in fact, not to hunt together) and this requires them to be able to inhibit what psychologists call "prepotent" actions (those using excessive exercise of power or influence) because failure to do so destabilises groups and causes their dispersal-so losing the benefit of being in the group (Dunbar, 2011). Particularly as numbers grow, what humans need are mechanisms that allow them to 
tolerate each other and to reduce the huge costs of living in close proximity. One such mechanism is wider social recognition of kinship ties noted above; another is the division and specialization of labour. Often a two-step process may be discerned: there is a need to solve the problem of how to manage large groups effectively in order to be able to solve an ecological problem (predation risk) (Dunbar \& Shultz, 2017). Where the first problem is solved, the second may be solved consequentially. Further cooperation emerges later as a derived benefit once these groups are established, and is usually predominantly between extended family members (reflecting Hamilton's kin selection mechanism that is derivative of the concept of inclusive fitness; Hamilton, 1964; 1975; Barrett et al., 2002), but may then be further elaborated.

\section{Society and Population}

As groups become larger, two patterns may be distinguished. The first involves the development of a segmentary society, in which a larger community might be made up of a number of lineages. Lineages would have leaders whose authority and status derive from their birth or seniority, with the group of lineage leaders acting as some kind of council of elders. The second pattern specifies that the larger the group, the more explicit is the exercise of authority and power, and the less egalitarian and more hierarchical the social organization. This second pattern arises particularly from how groups tend to interact, as they inevitably will, as they grow larger.

Diamond assists in the understanding of types of society, their interactions and the implications for population size and density. The tendency for population numbers to increase is interdependent with changes in patterns of social control and of economic transfers (Diamond, 1998: pp. 286-288). When certain conditions are met, competition between societies may give rise to societies of greater complexity (Diamond, 1998: p. 289). As numbers grow, systematic change in respect of the division and specialization of labour is crucial in two respects: it tends to increase average product per person while diminishing the tendency for conflict to arise, conflict which might lead to maiming and increased mortality. Paradoxically, in settled societies the designation of space from which people are substantially excluded may indirectly give rise to population growth, through its impact on the dispersal of population.

\section{Religion and Population}

Religious beliefs and organizations are highly variable in their precise nature but virtually ubiquitous (Smart, 1993: pp. 12-23; Mithen, 1999; Atran, 2002; Bloom, 2007; Wright, 2009), which invites explanation (Stark, 1990; Boyer, 2002; Boyd \& Richerson, 2005; Wade, 2009). In this connection, strategic-and arising out of theory of mind-is the tendency towards bifurcation in respect of types of human explanation or understanding: there can be explanation by reference to purposive (or personal) causation or explanation by reference to non-purposive 
(or non-personal) causation (Startup, 2020). Religion tends to arise in the early circumstances of mankind because the idea of agency and explanation in terms of reasons and purposes is being applied in contexts where we would expect non-purposive explanation to be appropriate. As Harari (2014: p. 54) affirms, "most scholars agree that animistic beliefs were common among ancient foragers". This, in its turn, bears upon the structuring of rational action; it could be rational, for instance, to dam a stream to store fresh-water, but also rational to ask or pray for rain. Religion therefore arose partly because there was familiarity with purposive agency but lack of clarity about its precise scope and limits. There is space here to make the additional comment that religion in its generality is an adjustment to the situation where personal death in a material sense is understood to be inevitable and is feared (Startup, 2020: pp. 354-355).

In its fully developed form religion possesses various aspects or dimensions: the practical and ritual, the experiential and emotional, the narrative or mythic, the ethical and legal, and the material (Smart, 1993). Religious groups are the largest which humans have created; they secure the social contract, particularly by promoting normative integration and social solidarity. A central concern here is the relation between religion and population. It has been argued that religion evolved as one of the behavioural mechanisms designed to facilitate community bonding (as numbers came to exceed 150) (Dunbar, 2020). The major religions existing at any particular date are to be understood as the survivors from a much larger pool; the group augmentation hypothesis (see above) helps situate the evolution of seemingly altruistic helping behaviour within them. There is good reason to judge that these "survivor" religions have traditionally encouraged a high level of fertility, partly because it is in their interests to do so. A high level here means one which is sufficient to promote gradual longer-term population growth despite such persistent and familiar patterns as high infant and high maternal mortality. In recent centuries, following rapid declines in age-specific mortality rates, the major religions have demonstrated varying degrees of flexibility by modifying their outlook on fertility to some extent, acknowledging the contribution of at least some types of birth control and family planning methods (Heaton, 2011). Nevertheless religion's overall contribution is generally to promote population growth. A specific way in which it does this is by discouraging or condemning suicide.

\section{Patterns in Prehistory and History}

In antiquity the population of hunter-gatherers tended to grow through expansion in space. Significantly, the crucially important phenomenon of agriculture arose independently in at least seven regions of the world (Scarre, 2005). The emergence of agriculture may only be understood once it is appreciated that various incremental stages are involved as are differing associated phenomena such as domestication, cultivation, herding and sedentism; there is also the important distinction between hoe agriculture and plough agriculture and the need 
to take full account of technologies of intensification. Population pressure contributed by leading hunter-gatherers to spread in ways made possible by technical modification, but the same kind of pressure sometimes resulted in intensive adjustment involving technical and organizational change.

A further evident tendency was for there to emerge more institutionalized social formations (states) and complex concentrated settlements (cities). The human tendency towards aggression played an important part. In association with these changes there is a tendency for kinship to decline in relative importance as a structuring principle although it always retains importance. That the same trends - towards food production, social complexity and urbanism-are found as independent developments in different parts of the globe points to the importance of gradual yet systematic change in social and technical organization i.e. in the patterns of cooperation (Scarre, 2005: p. 41).

Warfare between cities and states played its part in the formation of ever larger political entities. Recorded history is marked by the emergence of empires (Darwin, 2007) and subsequently nation states. A key feature of empire is the way in which the metropole confers a range of public goods throughout its territories (Waites, 1993; Abernethy, 2000; O’Brien, 2002: p. 4; Ferguson, 2003, 2004) thereby tending to generate a wider pattern of cooperation associated with a rising population. There is even a biological/ecological aspect to imperialism illustrated by the introductions by European colonisers of domesticated animals and plants (Crosby, 2004). Empire and population growth both played a part in the emergence of the nation-state system, initially in Europe. To a significant extent, a nation may be thought of as, "an imagined political community" (Anderson, 1991: pp. 6-7); implying that part of its reality concerns the use by its members of theory of mind e.g. in understanding the position and differing contributions of their geographically remote fellow citizens. Despite the occurrence of wars, a fundamentally cooperative framework of nations was thereby created-eventually on a worldwide basis (McGrew, 2004: p. 133). More recently there has followed a build-up of international and supra-national governance i.e. structures of higher-level cooperation which perform a moderating role. There is evidently a dynamic setting, conducive to a steadily rising population.

A further strategic element, the institution of money, in its physical form constitutes a focus of shared reference, at once symbolizing and constituting value. It promotes cooperative-market-style-trading relations of goods and services on a geographically-extended and virtually open-ended basis. To be more precise, its very existence structures interests in such a way that there is a tendency for the underlying potential to cooperate in trade relations to be realized together with a sharpening of the division of labour; its apotheosis is reflected in free trade. The institution has in-built dynamism tending to give rise to further related developments such as systems of borrowing and lending (perhaps at interest) and insurance; that dynamism is further manifested in the emergence of capitalism and ultimately finds expression in globalization.

In the human story rational action is evident from the outset but that type of 
orientation is more widely and more systematically expressed in association with the emergence of particular institutional forms-such as money. Of central importance is means-ends rationality where an objective judgment as to effectiveness and efficiency of means may be made in relation to the achievement of an empirically identifiable end; bureaucracy-mankind's greatest social invention according to Max Weber-is perhaps its deepest organizational expression. Complex societies generate conditions conducive to the wider and more general application of a rational approach; particularly germane to population is the rationality implied by the notion of family planning employed in recent centuries.

\section{Memes}

Following upon the development of thinking regarding the selfish gene, the notion of the "meme" was introduced, viewed as a second kind of replicator. The meme is a cultural item with a putative tendency to replicate i.e. to be passed on by non-genetic means, especially imitation. In one exposition Blackmore (2000: p. 43) affirms that "Imitation includes any kind of copying of ideas and behaviour from one person to another" (See also Dawkins, 2003). Further to the present study and its concern with cooperative genes it may be helpful to inquire into possible implications for the study of memes.

The pattern of explanation developed here is that the cooperative genes give rise to cooperation which tends to propagate the genes themselves. The cooperative activity is not viewed as static but has an open-ended potentiality for growth and development. An example may help to illustrate the link between changing patterns of cooperation and meme propagation. There has been a relative advance in the global use of the English language since the Second World War (for example, relative to French) and it is instructive to point to one "growth area". Air travel both of passengers and freight has built up substantially during the period leading to the emergence of a dense and complex web of routes. Given a need for there to be communication between pilots and ground crew, the potential problem is the sheer multiplicity of languages which might conceivably be involved. The problem has been surmounted by the agreement to use English in many of these contexts, which forms part of the pattern whereby English has come to dominate in non-native speakers' choice of a second language. Hence in this example replication of memes is an aspect of the growth of instances of cooperation between pilots and ground crews. Hence it is suggestive of the conclusion that the fate of memes is fundamentally bound up with associated cooperative activity.

It is informative to ask whether the same type of link is evident in other institutional spheres. There are a whole number of situations shaped by technological advance which have implications for vocabulary and patterns of communication. Looked at from one point of view half the words in the English language are now scientific and technical terms, but this primarily points up that the growth of terms is associated with a growth of cooperative contexts in which they are em- 
ployed.

Consider from this point of view the terminology of natural history or biology. Major figures such as Linnaeus and Darwin in effect inaugurated or developed further taxonomic programmes. The latter proposed that all species have descended from common ancestors and that the branching pattern of evolution resulted from a process he called natural selection. It followed that from that point in time-if not earlier-there would be a general interest in discovering new species and adopting and using names for them (possibly latinised) which would reflect their newly understood relationships. The development and use of the set of memes is hence essentially subordinate to a cooperatively undertaken scientific programme, to which individual investigators would understand themselves to be contributing.

Focusing particularly on language, one must remind oneself that there are primary and secondary usages. A main way in which languages grow is through metaphor and simile. In the middle ages a substantial vocabulary surrounded the practice of torture. Happily that practice declined along with some of its vocabulary, but this does not mean every reference to it has disappeared from linguistic usage. Thus we could say-just as Francis Bacon did—that scientific method involves "putting nature on the rack", or that a particular theory or policy suffered "the death of a thousand cuts", without necessarily feeling the horror at corresponding human suffering. However, it is quite evident that metaphor and simile are simply the fabric of communication in a whole number of cooperative contexts, far removed from those of their linguistic origins.

From these examples it is important not to draw the conclusion that changes in cooperative relationships somehow produce changes in cultural items such as vocabulary or patterns in language usage; rather these latter changes are an aspect of the former ones. But this leads to an interesting tentative conclusion. It is not that one is presented with two "replicators", the gene and the meme, which have their own distinctive lives but rather that the fate of the latter is interdependent with the activity to which the former gives rise, the gene being the single controlling replicator. The picture is of cooperative genes giving rise to cooperative behaviour which tends to propagate the genes, while the differing types of meme inhere in differing classes of cooperative relationship.

\section{Conclusion}

In a study drawing both from evolutionary biology and the social sciences, evidence and argument are supportive of the comprehensive application of selfish gene theory to the human population. At the centre of attention are the genes giving rise to characteristically-human cooperation using language and theory of mind; those genes may be judged to give rise to patterns of behaviour, even including celibacy and slavery, which initially may be felt to present insuperable problems. The key idea is that the behaviour which tends to propagate the cooperative genes may be "at cost" to the genes of some who may be party to the cooperation itself. 
A primary insight is that cooperation using language and theory of mind is itself interdependent with full human conceptualization of a world of objects and their own place in it as embodied beings; so also is it significant that a stabilising normative element tends to arise within cooperation, which is the crucible for the development of morality. Importantly, too, humans can have reasons for action which are "desire-independent" and they can "delay gratification", which gives rise to a behavioural "range of options"; hence the way is open to an extended and flexible elaboration in the human division of labour, a centrally important condition for long-term population growth. Human capacities inhering in, or arising out of, the ability to cooperate are also responsible for a vitally important long-term process-the domestication of animals and plants.

This study increases understanding of the link between zoology and social anthropology: there is enhanced insight into the difference between animal and human sexual behaviour and explanation of the emergence of kinship systems involving the social recognition of blood ties. A framework of kinship and affinal links renews society and facilitates population growth. The pattern of that growth may be further understood using Trivers' Parent-Offspring Conflict Theory and Lack's Principle. A greater level of complexity in societies tends to arise from competition between societies at a simpler level of complexity. It is not the case that various independent variables cause growth in the dependent variable of population size; rather, a set of analytically distinguishable elementsincluding societal complexity, the rate of technological innovation, food production, and population size and density-inter-affect one another within the context of systematic change.

In respect of the conditions for population growth, a suggestive orienting idea is that of the social contract: what are needed are mechanisms which allow humans to tolerate each other and reduce the costs of living in close proximity: the primary one is development or reshaping of the division and specialisation of labour (both within groups and in space), which tends to increase productivity while diminishing the tendency for conflict to occur. That structural elaboration is interdependent with the high degree of flexibility which humans exhibit. The fact is that humans can be observed to survive-and propagate-in very unequal situations and even when subordinated in coercive-cooperative relationships such as slavery. Significantly too religious groups are the largest which humans have created; they promote normative integration and social solidarity. Religion's overall contribution to population is generally such as to promote its growth.

In the understanding of prehistory and history, it is of the greatest significance that the same trends-including food production, social complexity and urbanism-arose as independent developments at different times and places on the globe; the explanation lies in the precise character of human cooperative behaviour. Similarly significant is the emergence of differing kinds of political entities, including states, empires, and eventually nation states, within which condi- 
tions tend to be created which are favourable to population growth. Important features of complex societies which sustain and extend human cooperation are the built environment, writing and money.

While rationality has always inhered in human behaviour, the more extended adoption of a rational approach to aspects of life (e.g. in respect of one's own fertility) is interdependent with the development of institutional forms. There is a long-term trend-manifested in globalization-for humans to reconfigure the external world so as to maximise the possibilities for their own cooperation in it. Contrary to one's initial expectation, the threat or experience of violence and war played an essential part in the creation of the conditions for long-term population growth. In addition, however, it is also of the greatest significance that societal and institutional change over time-focusing on such shared ideas as property and national sovereignty-has realized a latent potential for wider cooperation without recourse to war.

The global picture of recent decades is of steady and sustainable population growth; the 2020-2021 pandemic could alter that, but already it is intensifying new types of global cooperation geared to combating increases in morbidity and mortality, for example in the development and distribution of vaccines. However, sustainable overall growth in population is accompanied by a rising proportion who are "paying a substantial cost" in terms of loss of their own potential fertility; plainly those in the European nation states fall into the latter category. The significance of the reduced family size in western societies is sometimes presented as a kind of "release from the genetic treadmill" but this is not so. Those who reproduce most will contribute most to the species' future gene pool. The issue again concerns Lack's principle (see above). The changed conditions for fertility decision-making are: high rates of offspring survival and the dramatically increased costs of rearing, especially with the arrival of a knowledge economy, it being very expensive to rear children and place them effectively in the social and marriage markets.

It arises from this account that the gene is the single controlling replicator; the notion of the meme as a second independent replicator cannot do the work assigned to it. The theory of the selfish gene in an exclusively individualistic form fails to grasp the complexity of human life. It is the move to focus on cooperative genes which provides the needed additional element, the key to grasping complexity. The future expression of the selfishness of the human cooperative genes is essentially open-ended. What is clear is that it could have implications for, and frequently be "at cost" to, the propagation of any of the other genes of other life forms both on this planet and, conceivably also, elsewhere.

\section{Acknowledgements}

The author wishes to thank Robin I. M. Dunbar, Professor of Evolutionary Psychology at Oxford University, for his detailed comments on an earlier draft of this article and his support in furthering this project. 


\section{Conflicts of Interest}

The author declares no conflicts of interest regarding the publication of this paper.

\section{References}

Abernethy, D. B. (2000). The Dynamics of Global Dominance: European Overseas Empires 1415-1980. Yale University Press.

Anderson, B. R. (1991). Imagined Communities: Reflections on the Origin and Spread of Nationalism. Verso.

Atran, S. (2002). In Gods We Trust: The Evolutionary Landscape of Religion. Oxford University Press.

Axelrod, R. (1984). The Evolution of Cooperation. Basic Books.

Barrett, L., Dunbar, R., \& Lycett, J. (2002). Chapter 2. Basics of Evolutionary Theory. In Human Evolutionary Psychology. Princeton University Press. https://doi.org/10.1007/978-1-137-23550-3 2

Beattie, J. (1993). Other Cultures: Aims, Methods and Achievements in Social Anthropology. Routledge and Kegan Paul.

Blackmore, S. (2000). The Meme Machine. Oxford University Press.

Bloom, P. (2007). Religion Is Natural. Development Science, 10, 147-151. https://doi.org/10.1111/j.1467-7687.2007.00577.x

Blumer, H. (1969). Symbolic Interactionism: Perspective and Method. Prentice-Hall.

Bowles, S., \& Gintis, H. (2013). A Cooperative Species: Human Reciprocity and Its Evolution. Princeton University Press.

Boyd, R., \& Richerson, P. J. (2005). The Origin and Evolution of Cultures. Oxford University Press.

Boyer, P. (2002). Religion Explained: The Human Instincts that Fashion Gods, Spirits and Ancestors. Vintage Books.

Carruthers, P., \& Smith, P. K. (1996). Theories of Theories of Mind. Cambridge University Press. https://doi.org/10.1017/CBO9780511597985

Crosby, A. W. (2004). Ecological Imperialism: The Biological Expansion of Europe: 900-1900. Cambridge University Press. https://doi.org/10.1017/CBO9780511805554

Darwin, J. (2007). After Tamerlaine: The Global History of Empire Since 1405. Allen Lane. https://doi.org/10.3366/brs.2008.0011

Dawkins, R. (1976, 2006). The Selfish Gene (First and Thirtieth Anniversary Editions). Oxford University Press.

Dawkins, R. (1980). Good Strategy or Evolutionarily Stable Strategy. In G. W. Barlow, \& J. Silverberg (Eds.), Sociobiology: Beyond Nature/Nurture (pp. 331-367). Westview Press. https://doi.org/10.4324/9780429306587-14

Dawkins, R. (2003). Chapter 3.2. Viruses of the Mind. In A Devil's Chaplain. Weidenfeld \& Nicolson.

Dawkins, R. (2010). The Greatest Show on Earth: The Evidence for Evolution. Black Swan.

Diamond, J. (1998). Guns, Germs and Steel: A Short History of Everybody for the Last 13,000 Years. Vintage.

Dunbar, R. I. M. (1991). On Sociobiological Theory and the Cheyenne Case. Current 
Anthropology, 32, 169-173. https://doi.org/10.1086/203934

Dunbar, R. I. M. (1996). Grooming, Gossip and the Evolution of Language. Harvard University Press.

Dunbar, R. I. M. (2011). Chapter 2. The Social Brain and Its Relevance to Social Psychology. In J. P. Forgas, M. G. Haselton, \& W. von Hippel (Eds.), Evolutionary Psychology and Social Cognition. Psychology Group, Taylor \& Francis Group.

Dunbar, R. I. M. (2020). Religion, the Social Brain and the Mystical Stance. Archive for the Psychology of Religion, 42, 46-62. https://doi.org/10.1177/0084672419900547

Dunbar, R. I. M., \& Shultz, S. (2017). Why Are There So Many Explanations for Primate Brain Evolution? Philosophical Transactions of the Royal Society B, 372, Article ID: 20160244. https://doi.org/10.1098/rstb.2016.0244

Ferguson, N. (2003). Empire: How Britain Made the Modern World. Penguin.

Ferguson, N. (2004). Colossus: The Rise and Fall of the American Empire. Penguin.

Fox, R. (1984). Kinship and Marriage: An Anthropological Perspective. Cambridge University Press.

Grafen, A., \& Ridley, M. (2006). Richard Dawkins: How a Scientist Changed the Way We Think. Oxford University Press.

Haig, D. (1993). Genetic Conflicts in Human Pregnancy. The Quarterly Review of Biology, 68, 495-532. https://doi.org/10.1086/418300

Hamilton, W. D. (1964). The Genetical Evolution of Social Behaviour I and II. Journal of Theoretical Biology, 7, 1-16, and 17-52. https://doi.org/10.1016/0022-5193(64)90039-6

Hamilton, W. D. (1975). Innate Social Aptitudes of Man: An Approach from Evolutionary Genetics. In R. Fox (Ed.), Biosocial Anthropology (pp. 133-153). Malaby Press.

Harari, Y. N. (2014). Sapiens: A Brief History of Humankind. Harvill Secker.

Heaton, T. B. (2011). Does Religion Influence Fertility in Developing Countries? Population Research and Policy Review, 30, 449-465.

https://doi.org/10.1007/s11113-010-9196-8

Helgason, A., Sigurðardóttir, S., Gulcher, J. R., Ward, R. and Stefánsson, K. (2000). mtDNA and the Origin of the Icelanders: Deciphering Signals of Recent Population History. American Journal of Human Genetics, 66, 999-1016. https://doi.org/10.1086/302816

Keeley, L. H. (1996). War before Civilization: The Myth of the Peaceful Savage. Oxford University Press.

Kingma, S. A., Santema, P., Taborsky, M., \& Komdeur, J. (2014). Group Augmentation and the Evolution of Cooperation. Trends in Ecology \& Evolution, 29, 476-484. https://doi.org/10.1016/j.tree.2014.05.013

Kokko, H., Johnstone, R. A., \& Clutton-Brock, T. H. (2001). The Evolution of Cooperative Breeding through Group Augmentation. Proceedings of the Royal Society of London. Series B, Biological Sciences, 268, 187-196. https://doi.org/10.1098/rspb.2000.1349

Lack, D. (1954). The Regulation of Animal Numbers. Clarendon Press.

McGrew, A. (2004). Power Shift: From National Government to Global Governance? In D. Held (Ed.), A Globalizing World? Culture, Economics, Politics. Routledge.

Mithen, S. (1999). The Prehistory of the Mind: The Cognitive Origins of Art, Religion and Science. Thames \& Hudson.

O'Brien, P. K. (2002). The Pax Britannica and American Hegemony: Precedent, Antecedent or Just Another History? In P. K. O’Brien, \& A. Cleese (Eds.), Two Hegemonies: Britain 1846-1914 and the United States 1941-2001. Ashgate. 
Pagel, M. (2012). Wired for Culture: The Natural History of Human Cooperation. Allen Lane.

Petersen, W. (1969). Population. Collier-Macmillan.

Reuter, M., \& Montag, C. (2016). Genes and Human Decision-Making. In M. Reuter, \& C. Montag (Eds.), Neuroeconomics (pp. 67-83). Springer. https://doi.org/10.1007/978-3-642-35923-1 4

Santos, L. R., \& Rosati, A. G. (2015). The Evolutionary Roots of Human Decision Making. Annual Review of Psychology, 66, 321-347. https://doi.org/10.1146/annurev-psych-010814-015310

Scarre, C. (2005). Chapter 5. The World Transformed: From Foragers and Farmers to States and Empires. In C. Scarre (Ed.), The Human Past: World Prehistory \& The Development of Human Societies. Thames \& Hudson.

Searle, J. R. (2010). Making the Social World: The Structure of Human Civilization. Oxford University Press. https://doi.org/10.1093/acprof:osobl/9780195396171.001.0001

Smart, N. (1993). The World's Religions. University Press.

Stark, R. (1990). Micro Foundations of Religion: A Revised Theory. Sociological Theory, 17, 264-289. https://doi.org/10.1111/0735-2751.00080

Startup, R. (2014). The Cooperative Being: Humanity and the Selfish Gene. Cronfa. https://cronfa.swan.ac.uk/Record/cronfa17960\#.U85lf7GGeic

Startup, R. (2019). Structuring a Philosophical Approach. Open Journal of Philosophy, 9, 452-469. https://doi.org/10.4236/ojpp.2019.94028

Startup, R. (2020). Religion: Its Origins, Social Role and Sources of Variation. Open Journal of Philosophy, 10, 346-367. https://doi.org/10.4236/ojpp.2020.103023

Trivers, R. L. (1974). Parent-Offspring Conflict. American Zoologist, 14, 249-264. https://doi.org/10.1093/icb/14.1.249

Voland, E. (1990). Differential Reproductive Success within the Krummhörn Population (Germany, 18th and 19th Centuries). Behavioral Ecology and Sociobiology, 26, 65-72. https://doi.org/10.1007/BF00174026

Voland, E., \& Beise, J. (2002). Opposite Effects of Maternal and Paternal Grandmothers on Infant Survival in Historical Krummhörn. Behavioral Ecology and Sociobiology, 52, 435-443. https://doi.org/10.1007/s00265-002-0539-2

Wade, N. (2009). The Faith Instinct: How Religion Evolved and Why It Endures. Penguin Press.

Waites, B. (1993). Europe and the Third World. In B. Waites (Ed.), Europe and the Wider World. The Open University.

Williams, G. C. (1966a). Adaptation and Natural Selection. Princeton University Press.

Williams, G. C. (1966b). Natural Selection, the Costs of Reproduction, and a Refinement of Lack's Principle. The American Naturalist, 100, 687-690. https://doi.org/10.1086/282461

Wright, R. (2009). The Evolution of God: The Origins of Our Beliefs. Little Brown. 